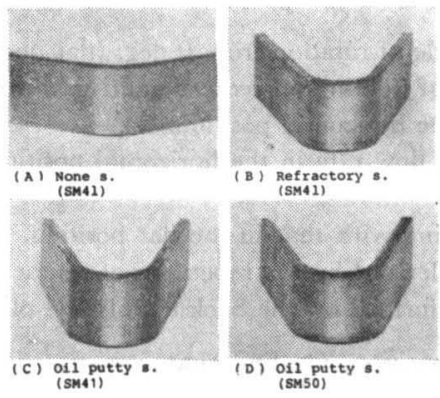

Fig. 9 Results of bending tests

Table 7 Results of Charpy impact tests $\left(0^{\circ} \mathrm{C}\right)$

\begin{tabular}{l|r}
\hline \hline $\begin{array}{l}\text { Weld } \\
\text { No. }\end{array}$ & $\begin{array}{c}\text { Impact yalue } \\
\left.\text { (J/cm }{ }^{2}\right)\end{array}$ \\
\hline 1 & $22(19-16)$ \\
2 & $32(22-42)$ \\
3 & $40(33-48)$ \\
4 & $62(57-66)$ \\
5 & $73(68-78)$ \\
\hline SM41 & $43(38-49)$ \\
SM50 & $147(145-151)$ \\
\hline
\end{tabular}

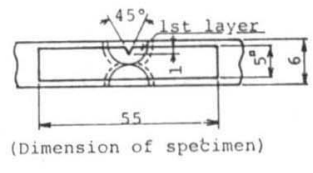

てある.なお, 嘼撃值は数個の武験片の平均値で示して あるが，参考のためその最小值と最大值を括弧中に示し た. 表より S M41 材においては, シールト゚しない場合 の衝撃值が約 $22 \mathrm{~J} / \mathrm{cm}^{2}$ であるが，てれに対してパテシ ールド法を用いた場合のそれは $40 \mathrm{~J} / \mathrm{cm}^{2}$ で母材のそれ の $43 \mathrm{~J} / \mathrm{cm}^{2}$ にかなり近い值を示している。一方, SM50 材においては, パテシールド法による水中溶接部の衝撃 值は $62 \mathrm{~J} / \mathrm{cm}^{2}$ で, 大気中溶接部の $73 \mathrm{~J} / \mathrm{cm}^{2}$ に近い值を 示しており，実用上問題ないととがわかる.

以上の結果を総合すると, シールド法によって溶接部 の冷却速度の低下を計れば, 湿式水中溶接における溶接

部の延性及び靬性を改善し得るととが明らかとなった。

\section{4, 結}

得られた主な結果は以下のようにまとめられる。

(1) シールド法を用いるととによって湿式水中溶接部 の冷却速度を低下し，その硬化を防止できる。

(2) シールドなし，耐火材シールド及びパテシールド による水中溶接ボンド部の冷却速度 $(R)$ 及び $800^{\circ} \mathrm{C}$ から $500^{\circ} \mathrm{C}$ と $300^{\circ} \mathrm{C}$ までの冷却時間 $\left(S_{500}, S_{300}\right)$ を溶接諸条件 から推定するための実験式を導いた。

(3) S M50 級鋼板の水中溶接に際して, 溶接部の冷 却速度 $R$ を $35^{\circ} \mathrm{C} / \mathrm{s}$ 以下 ( $S_{500}$ を $6 \mathrm{~s}$ 以上), 最高硬さ Hv 360 以下ないしは板厚 $9 \mathrm{~mm}$ 程度までをビート゚下割 れ防止の目安となしうる. この冷却速度は, パテシール ド法により容易に達成しうる。

(4) S M41 材及び S M50 材のいずれにおいても，パ テシールド法を用いて溶接部の冷却速度を緩和すれば, 十分な引張強さと，曲げ延性及び切欠き䩒性等を有する 水中溶接継手を得ることができる.

末尾ながら本研究にで協力頂いた慶応義熟大学理工学 部の蓮井淳教授及び本実験に協力された実験当時本塾大 学院の関水信之君 (現在日本鋼管侏) 及び岸信典君（現 在住友金属工業(侏)に感謝の意を表する。

\section{参考文 献}

1) 連井, 菅 : 溶訫, 43-8 (1974) p.767

2) 連井, 落 : 溶誌, 48-12 (1979) p. 1077

3) 菅: 溶論, 2-4 (1984) p.676

4) T. Brown, et al. : Underwater J., 6 (1973) p.202

5) H. Ozaki, et al. : Weld. J, 8 (1977) p.232 s

6) H. Hoffmeister : DVS 57, p. 91

7) 営: 溶論, 3-4 (1985) p.830

8）佐藤他：溶誌，51-8 (1982) p.665

9）䔎井，农川，菅：溶誌，42-1 (1973) p.18

10）浜崎，肺原：溶誌， 48-2 (1979) p.115

11) 衣川, 福島, 福島: 溶誌, 50-1 (1981) p.65

12) E. A. Silva, et al. : Weld. J., 50-6 (1971) p.406

\title{
湿式水中プラズマ溶接の横向姿勢への適用性*
}

\author{
福島孟**, 福島 貞夫**, 衣川 純一**
}

Applicability of Underwater Wet Plasma Welding with Developed Attachment to Horizontal Position Welding*

by Takeshi Fukushima**, Sadao Fukushima** and Junichi Kinugawa**

The applicability of underwater wet plasma welding in the horizontal position was examined by using a welding attachment developed. This assembly, which is designed simply, is attached to the front face of plasma torch.

Welding was carried out in pressurized city water. Appearances of weld beads, cooling cycles at weld bonds and hardnesses of weld metals and HAZ's were investigated by varying weld rotation and welding conditions.

The use of the developed attachment stabilizes a gas cavity formed by plasma jet and protects any molten pool in this cavity from the invasion of environmental water in the horizontal wet welding. This

\footnotetext{
*原稿受付 昭和61年12月 2 月 昭和 57 年度春季全国大会で発表

**正只金属材料技術研究所 Member, National Research

Institute for Metals
} 
leads to good welds.

Molten metal tends to hang down with increasing in the angle of rotation from 0 deg. (flat position) to $90 \mathrm{deg}$. (horizontal position). Therefore, from the standpoint of welding procedure, multi-pass welding with a reduced amount of weld metal may be advantageous in the horizontal position.

The ranges of adaptable plasma arc current and plasma gas flow rate in the horizontal position become narrow comparing with those in the flat position.

Cooling of welds in the horizontal position is rapid comparing with that in the flat position. This difference is caused by the fact that the dissipation of heat is accelerated by the repetition of contact with water flowing in immediately after the floating of steam bubbles formed on the backside of base plate.

Key Words: Underwater welding, Plasma welding, Welding position, Cooling characteristics, Plasma gas cavity.

\section{1. 緒}

洋上作業台や沖合人工島など海洋空間の利用にあたっ て, これらの構造物に万一局部的な破損が生じた時, 早 急に補修を行う必要がある. この時の補修溶接は, 垂直 に近い被溶接材に対して行うことが多く，てれに用いる 溶接は横向きあるいは立向姿勢での溶接が不可欠であ る.

さて, 湿式水中溶接において良好な溶接結果を得るた めの必須条件であるアーク発生用空洞の安定化を計る目 的で, 一般のガスシールドアーク溶接用に開発された噴 流水を用いる二重シールド法1) 水カーテン法2) は, 溶 接アークを保持する空洞は安定するが, 溶接䇢所全周が 噴流水に吸引されて生じた細泡で囲まれるので直接の目 視確認が不可能であり, かつ, との噴流水を発生させる ための付帯設備屯必要となるなど, 補修溶接に要求され る手軽さの面で検討の余地がある.

本研究では, プラズマジェットを併発するプラズマ溶 接法（湿式水中プラズマ溶接）が他の溶接法に比へ，下 向湿式水中溶接において溶接アークを保持するための空 洞形成能が大である ${ }^{3)}$ ととに着目し, 各種溶接姿勢にお いて良好な溶接結果を得るための簡便な溶接用保護具 (以下アタッチメントと称する) を開発4) し，本方法の 横向溶接への適用の可否を明らかにする目的で, $98 \times 10^{2}$ $\mathrm{MPa}$ までの静水圧下で溶接を行う場合の空洞形成の状 況, ビード外観, 冷却特性及び溶接部の硬さについて検 討を行い, アタッチメントの有効性を確認した。

\section{2. 実 験 方 法}

本実験遂行のために開発したアタッチメントを装着で きるようトーチノズル前面を改造した以外, 使用した設 備は既報3) と同一である.

アタッチメントは, Fig. 1 に示すでとくトーチノズル 前面に取付け, 加圧機構によって先端が母板と接触を保 ちつつ移動しうる固体㫮動壁をノズル孔を隔てて上下に 対向して設け，溶接線方向を開放にしてある。したがっ て, 溶接線方向から溶接状況が目視確認できる. また, 逃散ガスが大きな体積のまま浮上した場合，溶接䇢所を 保護する空洞の体積変化が大きく， かつ，不安定にな る. とれを防止するため, ガスの浮上方向に位置する摺 動壁に数個の小孔を設け，乙の小孔からガスを逸散させ て空洞の安定を得ている。 なお, アタッチメントは母板 と接触するため窒化硅素を用いてノズルと母板の絶縁を 計っている.

Fig. 2(A)にノズルに取付りたアタッチメントの状況を， 同(B)には母板上に設置した状況を示す。

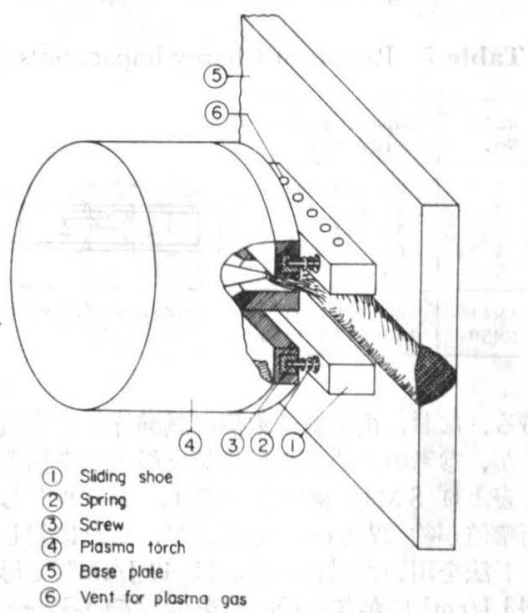

Fig. 1 Illustration of underwater plasma welding with welding attachment developed

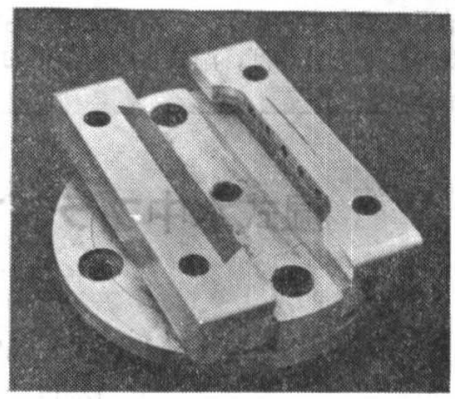

(A) Nozzle with attachment

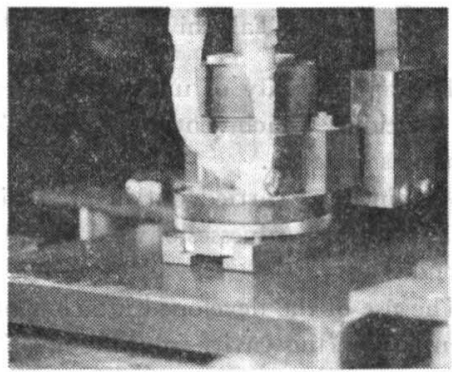

(B) Plasma torch set on a base plate

Fig. 2 Overall view of plasma torch and close-up of nozzle with attachment 
本実験に用いた母材は, 板厚 $19 \mathrm{~mm}$ の JIS-SM $41 \mathrm{~A}$ 鋼の熱圧材である.溶接は母板の溶接方向の傾斜角を $0^{\circ}$ 一定にし, 回転角を $0^{\circ}$ (下向き), $45^{\circ}$ 及び $90^{\circ}$ (横向き) に変えたビート゚溶接とした。

母板の化学成分を Table 1 に, また, 実験条件を Table 2 に示す. この条件は, 既報 ${ }^{3)}$ の下向溶接におい

Table 1 Chemical composition of base plate and its mechanical properties

\begin{tabular}{c|c|c|c|c|c|c|c}
\hline \multirow{2}{*}{ Base plate } & \multicolumn{6}{|c|}{ Chemical composition (wt \%) } & \multicolumn{2}{c|}{\begin{tabular}{c} 
Tensile \\
strength \\
\cline { 2 - 6 }
\end{tabular}} & $\mathrm{C}$ & $\mathrm{Si}$ & $\mathrm{Mn}$ & $\mathrm{P}$ & $\mathrm{S}$ & $\begin{array}{c}\text { Elongation } \\
\text { MPa })\end{array}$ & $(\mathrm{z})$ \\
\hline $\begin{array}{c}\text { JIS-SM4IA } \\
\text { 19 mm thick }\end{array}$ & 0.15 & 0.23 & 0.84 & 0.015 & 0.020 & 461 & 26 \\
\hline
\end{tabular}

て良好なビードが形成されるあのである.なお，作動力゙ ス流量は各水圧下における流量である.

\section{3. 実験結果及び考察}

\section{1 ガス空洞の挙動}

前述のごとく, 水中溶接においては溶接箇所を保護す る空洞の良否が溶接結果を支配する，そこで，母 板の回転角を変えた場合の空洞形成状態を稫察す るため，逆光(シュリーレン法5) )を用いて毎秒 2 コマで写真撮影した. なお, 撮影に際してアーク 光の母板表面における反射を防ぎ, かつ, 溶隔池 の形成による母板面形状の変化を避けるため, 厚 さ $7 \mathrm{~mm}$ の黒鉛板を母板相当材として用いた. ま た, 空洞内でアークを発生すると上述の現象が強調され 空洞の明瞭な撮影が困難になるのでアークの発生は中止 したが, 肉眼観察の結果ではアーク発生時の空洞形状は 幾分大となるあののその変化は少なかった，てのことか ら, 本報では実際の溶接においてもその形状に大差はな いあのとして, プラズマジェットのみによる空洞の挙動 について述べ。.

Fig. 3 は一例として, 水圧 $39 \mathrm{MPa}$, 母板の回転角を $90^{\circ}$ 一定にし, 作動ガス流量を $3,5,7 \mathrm{l} / \mathrm{min}$ に変化さ せた場合のアタッチメント未使用時の空洞形成状態を示 したあのである. 写真にみられるごとく，いずれの作動 ガス流量においても溶接箇所からガスが浮上すると同時

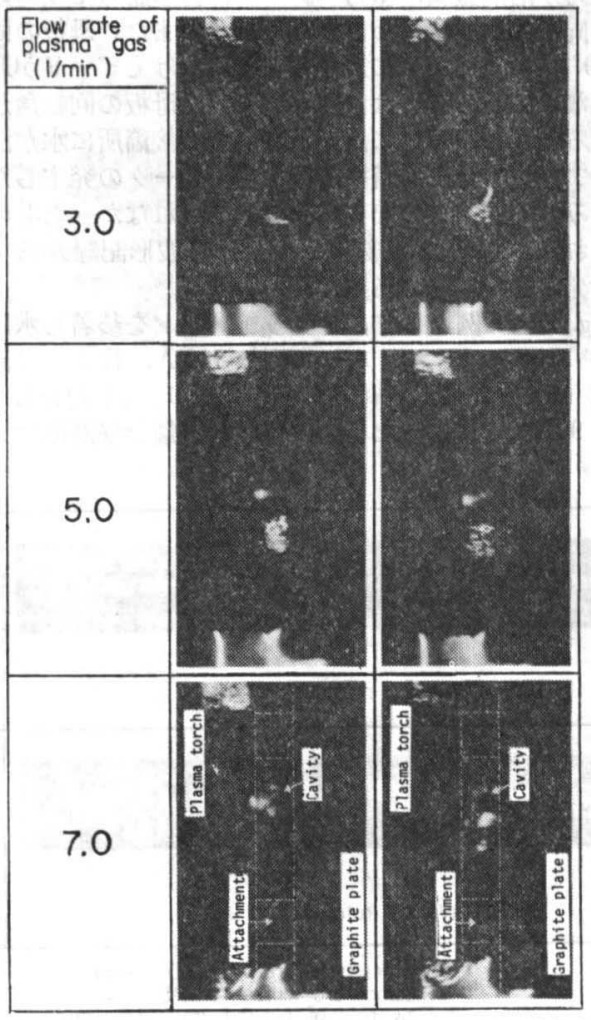

Water pressure : $39 \mathrm{MPo}$, Plasma jet current : $100 \mathrm{~A}$

Fig. 4 Shapes of gas cavities formed by plasma jet when welding attachment is applied

Fig. 3 Shapes of gas cavities formed by plasma jet when welding attachment is not applied 
に下方から水が浸入する場合と空洞が一時的に溶接簤所 を覆う場合とが絽返され, 不安定な保護状態となってい る.一方, Fig. 4 に示すごとく, 開発したアタッチメン 卜を装着した場合では, 低ガス流量では幾分水の浸入が みられるあのの, その度合はアタッチメントを装着しな い場合に比へてかなり少ない. 特に, 作動ガス流量 $7 \mathrm{l} /$ min では水の浸入はほとんどみられず安定な空洞が形成 されており, アタッチメント装着に上る空洞浮上狮止効 果が顕著であることが判る。このととは， $49 \times 10^{2}$ 及び $98 \times 10^{2} \mathrm{MPa}$ の水中においても同樣である.

\section{2 ビード外観と溶融形状}

アタッチメントを用いれば横向姿勢において空洞が安 定することが明らかになった。 そてで，板厚 $19 \mathrm{~mm}$ の JIS-SM 41 A 鍋を母板としてアタッチメントを装着し て横向きのビード溶接を行い, 得られるビードの形成状 態を検討した。

Fig. 5 は比較のための一例（板厚 $12 \mathrm{~mm} の \mathrm{SM} 41 \mathrm{~A}$ 鋼を使用) として, $98 \times 10^{2} \mathrm{MPa}$ の水圧下においてプ ラズマアーク電流 $125 \mathrm{~A}$, 作動ガス流量 $2.5 \mathrm{l} / \mathrm{min}$ 一定 そし, アタッチメントを装着せず, 母板の回転角を $45^{\circ}$ 及び $90^{\circ}$ に変えた場合のビード外観と横断面マク口組織 を示したあのである. 母板の回転角 $45^{\circ}$ におけるビード 外観は, 不斉でスラグの生成が著しく, マクロ組織にお いてあ気孔の生成がみられ, かつ, 溶融金属がガスの浮 上方向に押し上げられている. これは, ガスが浮上する 祭, アークがガスの浮上方向に引張られ, かつ, アーク の推力が溶隔金属の重力ベクトルに打ち勝ってガスの浮 上方向に作用するためと推察される. また，母板の回転 角 $90^{\circ}$ では, 母板上に穴が堀られるだけでビードが形成 されない.このととは, 前述のごとく母板の回転角が大 となるとガスの浮上に伴い下方から溶接䇧所に水が浸入 してアークの発生が断続的になり, アークの発生した部 分のみが溶融するのでビードが形成されなかったあのと 思われる. 事実, 溶接時の電流-電压波形記録からア一 クの発生は断続的であった.

Fig. 6 は一例として, アタッチメントを装着し水圧 98 $\times 10^{2} \mathrm{MPa}$ ，プラズマアーク電流 $100 \mathrm{~A}$, 作動ガス流量 $2.5 \mathrm{l} / \mathrm{min}$ 一定にし, 母板の回転角を $0^{\circ}$ (下向き), $45^{\circ}$ 及び $90^{\circ}$ に変化させた場合のビード外観と横断面マクロ
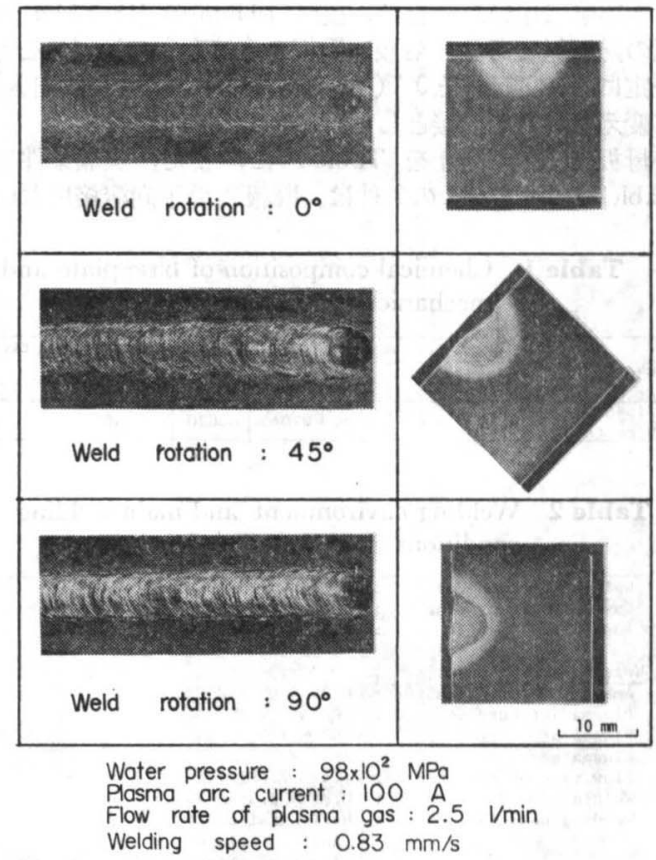

Fig. 6 Appearances of weld beads and their photomacrographs in each weld rotation when welding attachment is applied

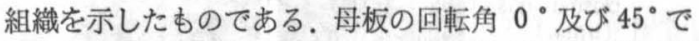
は良好なビードが得られているが， $90^{\circ}$ では前二者に比 べてやや不斉なビードとなっている，てのととは，前述 のどとく母板の回転角が大となるに伴い溶接箇所へ水が 浸入する度合む大となり，アークが不安定になり易くな るためと思われる.これに関しても, 電圧波形記録から 母板の回転角 $90^{\circ}$ の場合前二者よりやや不安定であるこ とを確認している. また, マク口組織においては, 母板 の回転角が大となるに伴い溶融金属がたれ下る傾向が大 となっている. これは, アタッチメントを装着しない場 合に溶融金属が押上げられるのと異なり，ガスの浮上方 向に位置する摺動壁によってガスの浮上が抑制され，か つ,アーク推力も母板之直角に作用する ようになり, 溶融金属の重力ベクトルが 浮上ガスと溶融金属表面の摩擦力などの 力に打ち勝って溶融金属は押上げられる ととなく多少たれ下がるようになるあの と思われる.なお，このととは水圧39及 び $49 \times 10^{2} \mathrm{MPa}$ であ同様であった。

Fig. 7 は, 水圧 $39 \mathrm{MPa}$, 作動ガス流 量 $5 \mathrm{l} / \mathrm{min}$ 及び母板の回転角 $90^{\circ}$ 一定に し，プラズマアーク電流を変化させた場 合のビード外観, マクロ組織及び放射線 透過写真を示したあのである.

ピードは, プラズマアーク電流の増加 に伴って溶融量が増しその幅及び深さと あに大となるが, 放射線透過写真にみら れるごとく気孔などの欠陥はみられな い.しかし，マクロ組織にみられるごと く,プラズマアーク電流が増し溶融量が

Fig. 5 Appearances of weld beads and its photo-macrograph when welding attachment is not applied 




Water pressure : $39 \mathrm{MPa}$, Flow rate of plasma gos : $5 \mathrm{~V} / \mathrm{min}$, Welding speed : $0.83 \mathrm{~mm} / \mathrm{s}$

Fig. 7 Influence of plasma arc current on weld bead appearances, their radiographs and weld metal profiles

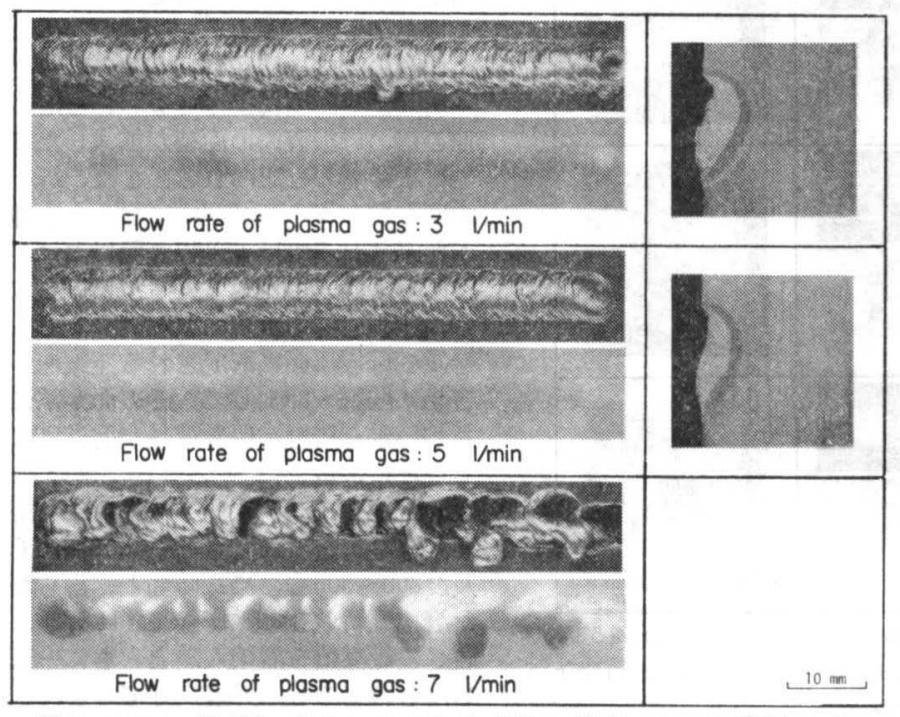

Water pressure : $39 \mathrm{MPa}$, Plasma arc current : $100 \mathrm{~A}$, Welding speed : $0.83 \mathrm{~mm} / \mathrm{s}$

Fig. 8 Influence of plasma gas flow rate on weld bead appearances, their radiographs and weld metal profiles.

増すととあに溶融金属が下方にたれ下る度合が大とな る. したがって, 横向溶接を行う場合は既報 ${ }^{32}$ の下向溶 接の適正溶接電流 100 200 A に比べてその範囲が狭く なるととが判る。とれは陸上での溶接と同様である.

Fig. 8 は, 水圧 $39 \mathrm{MPa}$, プラズマアーク電流 $100 \mathrm{~A}$ 及び母板の回転角 $90^{\circ}$ 一定にし, 作動ガス流量を変化さ せた場合のビード外観，マクロ組織及び放射線透過写真 を示したあのである。ビードは, 作動ガス流量 3 及び $5 l / \mathrm{min}$ ではその外観, マク口組織と屯大差なく, 放射線 透過写真においてあ欠陥はみられない。しかし, $7 \mathrm{l} / \mathrm{min}$ ではビードを形成しておらず, 過度の作動ガス流量の増
加は前述のごとくガス空洞の形成には 寄与するあののビード形成にはかえっ て有害であるととが示された.このと とは, 作動ガス流量の増加に伴いプラ ズマジェットの推力が大となり溶融池 を乱すためと思わ扎る．すなわち，作 動ガス流量についてもプラズマアーク 電流と同様, 下向溶接に比ぺてその適 正範囲が狭くなる。

以上は溶接速度を $0.83 \mathrm{~mm} / \mathrm{s}$ 飞一 定した場合のプラズマアーク電流及び 作動ガス流量がビード形成に与える影 響を例示したあのであるが，てれら一 連の実験を通して各水圧下におりる丁 一ク電流及び作動ガスの上限は母板の 回転角 $45^{\circ}$ 及び $90^{\circ}$ に対して, 水圧 39 $\mathrm{MPa}$ では $125 \mathrm{~A}, 5 \mathrm{l} / \mathrm{min}$, 水圧 $49 \times$ $10^{2}$ 及び $98 \times 10^{2} \mathrm{MPa}$ における母板の 回転角 $45^{\circ}$ では $125 \mathrm{~A}, 2.5 \mathrm{l} / \mathrm{min}$ ま た, 母板の回転角 $90^{\circ}$ では $110 \mathrm{~A}$, $2.5 \mathrm{l} / \mathrm{min}$ であるてとが判明した.

さて, 既に下向溶接において溶接金 属量が気孔の生成に関係するととが知 られている ${ }^{6)}$. との点化着目して溶接入 熱之溶融断面積の関係を検討した. Fig. 9 はこの関係を示したあのである. 同図 から，いずれの水圧下及び母板角度にお いても欠陥のない良好な溶接部が得られ るのは溶融断面積がほほ $65 \mathrm{~mm}^{2}$ 以内で ある.したがって, 実際の溶接にあたっ ては溶融断面積が $65 \mathrm{~mm}^{2}$ 以内になるよ うに溶接条件を設定すべきである.

外観が良好で, かつ, 気孔を含まない 溶接金属を得るためには1 1゚スで得られ る溶接金属量を增女ないととが判った。 このととは, 施工時の能率を考えた場合 に不利である. そこで, 溶接速度を増し うるかを検討した。

Fig. 10 は一例として, 水圧 $49 \times 10^{2}$ $\mathrm{MPa}$, プラズマアーク電流 $100 \mathrm{~A}$, 作動 ガス流量 $2.5 \mathrm{l} / \mathrm{min}$ 及び母板の回転角 $90^{\circ}$ 一定にして溶接速度を $0.83,1.67$, $2.50 \mathrm{~mm} / \mathrm{s}$ と変化させた場合のビード外 観, 横断面マク口組織及び放射線透過写 真を示したものである. 溶接速度の増加 に伴って溶融量か減少しているが, 計算 上の溶接入熱の減少に対応するほど顕著でない，また， いずれも気孔等の欠陥は生じていない。したがって，施 工面から考えると, 狭められた許容プラズマアーク電流 範囲において溶接速度を増加させて多首溶接を行うこと が有利と思われる。

\section{3 溶接部の冷却特性と硬さ}

湿式水中溶接においては, 水の冷却作用が溶接部の性 能を低下させることは周知である. 特に, 下向溶接に比 べて横向きあるいは立向溶接では母板表裏面の影響を受 け易く冷却が急峻になるととが知られている7)。こて で, 既報8) と同様の方法で横向溶接における溶接部の冷 


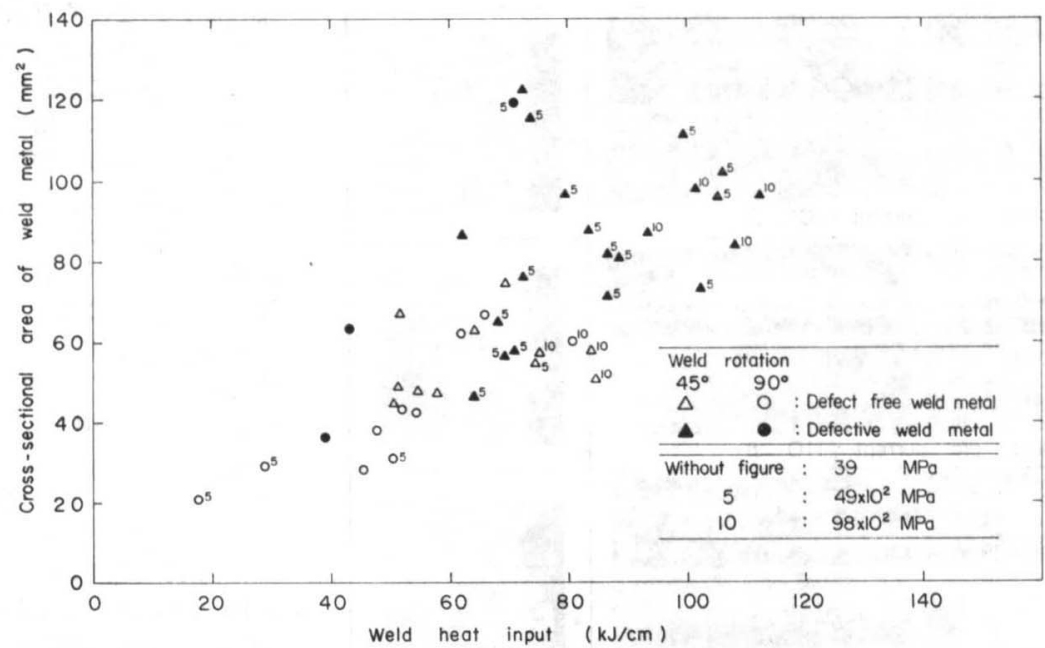

Fig. 9 Relation between cross-sectional area of weld metal and weld heat input

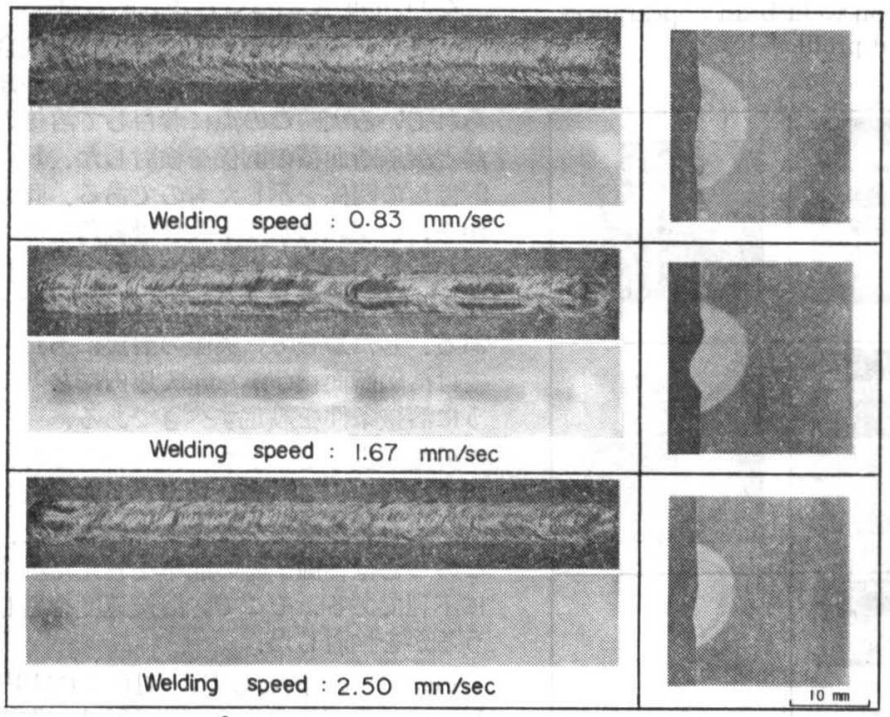

Water pressure : $49 \times 10^{2} \mathrm{MPa}$, Plasma arc current : $100 \mathrm{~A}$, Flow rate of plasma gas: $2.5 \mathrm{~V}$ min

Fig. 10 Influence of welding speed on weld bead appearances, their radiographs and weld metal profiles

却特性と硬さについて検討した。

Fig. 11 は, $39 \mathrm{MPa}$ の水圧下でアタッチメントを装着 して母板の回転角を変えた場合と下向きでアタッチメン 卜を装着しない場合の命却曲線を示したあのである.な お，それぞれの冷却曲線に相当する入熱を図中に記入し てある. 下向きでアタッチメントを装着した場合と装着 しない場合における命却時間は，溶接入熱がほぼ等しい に屯かかわらず前者が後者より延長している. 例えば, $800 \sim 500^{\circ} \mathrm{C}$ の冷却時間では約 2 秒前者の方が延長して おりアタッチメントの効果が影著であることが判る。一 方, アタッチメントを装着して母板の回転角を変えた場 合, 母板の回転角 $0^{\circ}$ (下向き) と $45^{\circ}$ では $45^{\circ}$ の方が入 熱が大であるにあかかわらず冷却が急峻となっている. $45^{\circ}$ と $90^{\circ}$ では冷却時間に大差はみられない.
下向溶接においては, 母板表面加ら の熱逃散が冷却過程を支配する大きな 因子であるととが示されている7)。こ のととから, アタッチメントを装着し た場合の冷却の緩和は, 空洞の安定と 空洞及び指動壁によって覆われる溶融 池近傍の母板表面の面積が拡大したて とによるあのと思われる. また, 母板 の回転角が $45^{\circ}$ 及び $90^{\circ}$ そなると冷却 が促進されるのは, 母板表面における 空洞が下向きに比ぺて浮上し易くな り，空洞に覆われる面積が減少するこ と及び母板裏面に形成される蒸気塊が 容易に離脱・浮上して, その面が常に 新しい水と接触を保ち放熱が促進され るととによる。

Table 3 は, 各水圧下で得られた冷 却曲線をむとにして求めた $800 \sim 500^{\circ} \mathrm{C}$ 及び $800 \sim 300^{\circ} \mathrm{C}$ の令却時間之, 得られ た溶接金属並びに熱影響部 (HAZ)の 硬さの最高值を溶接入熱ととあに一覧 したものである. 外観良好でほとんど 気孔を含まない溶接金属が得られる条 件下での冷却は, 同一母板回転角において水圧の増加に 伴って延長される傾向が認められる。しかし, これらに 対応した HAZ の最高硬さは Hv 353〜390 程度で, しか も冷却時間との相関は認められない，なお，最高硬さが

Table 3 Weld heat input, cooling time from $800^{\circ} \mathrm{C}$ to $500^{\circ} \mathrm{C}$ and Vickers hardness of welds

\begin{tabular}{|c|c|c|c|c|c|}
\hline \multirow{2}{*}{$\begin{array}{l}\text { Water } \\
\text { presuure } \\
\left(\times 10^{2} \mathrm{MPa}\right)\end{array}$} & \multirow{2}{*}{$\begin{array}{l}\text { Angle of } \\
\text { rotation } \\
\left({ }^{\circ}\right)\end{array}$} & \multirow{2}{*}{$\begin{array}{l}\text { Weld heat } \\
\text { input } \\
(\mathrm{kJ} / \mathrm{cm})\end{array}$} & \multirow{2}{*}{$\begin{array}{l}\text { Cooling time } \\
\text { from } 800^{\circ} \mathrm{C} \text { to } \\
500^{\circ} \mathrm{C}(\mathrm{sec})\end{array}$} & \multicolumn{2}{|c|}{$\begin{array}{l}\text { Vickers hardness of } \\
\text { welds (1oad: } 1 \mathrm{~kg} \text { ) }\end{array}$} \\
\hline & & & & Weld metal & $\mathrm{HAZ}$ \\
\hline 0.39 & $\begin{array}{l}45 \\
90\end{array}$ & $\begin{array}{l}80 \\
74\end{array}$ & $\begin{array}{l}5.3 \\
4.8\end{array}$ & $\begin{array}{l}183 \\
180\end{array}$ & $\begin{array}{l}373 * \\
373\end{array}$ \\
\hline 49 & $\begin{array}{l}45 \\
90\end{array}$ & $\begin{array}{l}85 \\
86\end{array}$ & $\begin{array}{l}6.0 \\
6.6\end{array}$ & $\begin{array}{l}190 \\
183\end{array}$ & $\begin{array}{l}390 \\
368\end{array}$ \\
\hline 98 & $\begin{array}{l}45 \\
90\end{array}$ & $\begin{array}{l}105 \\
123\end{array}$ & $\begin{array}{l}5.8 \\
7.9\end{array}$ & $\begin{array}{l}165 \\
157\end{array}$ & $\begin{array}{l}353 \\
358\end{array}$ \\
\hline
\end{tabular}

* Maximum value 


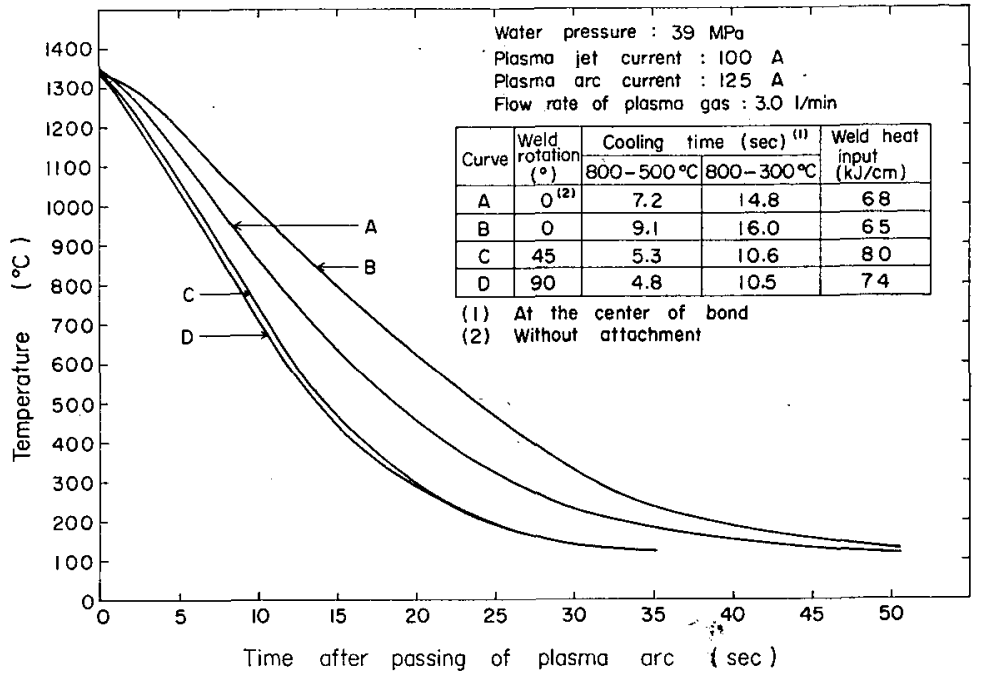

Fig. 11 Cooling curves from peak temperature in each weld irotation

既報8)のそれら(Hv 322〜330) と比べて幾分高いのは， 供試母材の G 量が $0.15 \%$ と既報8)におりるそれと比べて 0.02\%高いことによる.一方, 溶接金属の硬さは $\mathrm{Hv}$

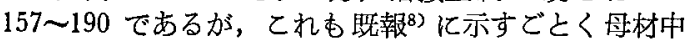
の C, Si，Mn がアーク雷囲気中の水蒸気によって酸化 され，それらの量が減じているためである。

\section{4. 結言}

加圧静水下において，開発した溶接用保護具（アタッ チメント）を用いた湿式水中プラズマ溶接を行い，その 横向溶接への適用の可否について検討した。

得られた結果を以下に要約する。

1）横向溶接への適用にあたって，開発したアタッチ メントを用いれば空洞が安定し，溶接筒所への水の浸入 が抑制され良好な溶接が行える。

2）母板の回転角加 $0^{\circ}$ (下台き) 加 $590^{\circ}$ (横向き) になるに伴い，溶融金属が下方にたれ易くなる，したが って，横向溶接においては溶融量を淢じて多層溶接を行 うことが施工上有利と思われる。

3）横向溶接においては,プラズマアーク電流及び作 動ガス流量いずれす下向溶接に比べて，良好な溶接部を 得る適正条件範囲が狭くなる。本実験におけるそれは， 水圧 $39 \mathrm{MPa}$ において母板の回転角 $45^{\circ}$ 及び $90^{\circ}$ いずれ においてあプラズマアーク電流 $125 \mathrm{~A}$, 作動ガス流量 5 $l / \mathrm{min}, 49 \times 10^{2}$ 及び $98 \times 10^{2} \mathrm{MPa}$ において母板の回転角 $45^{\circ}$ では $125 \mathrm{~A}, 2.5 \mathrm{l} / \mathrm{min}$, また, 母板の回転角 $90^{\circ}$ で は $110 \mathrm{~A}, 2.5 \mathrm{l} / \mathrm{min}$ である.さらに，いずれの水生及び
母板の回転角において 溶融断面積をほほ $65 \mathrm{~mm}^{2}$ 以内 になるよう溶接条件を設定すれば久陥のない良好な溶接 部が得られる。

4）溶接部の令却は，下向きから横向きになるに伴っ て急峻になる。これは，母板表裹面における熱伝達が促 進されることによる．母板の回転角 $45^{\circ}$ と $90^{\circ}$ では冷却 時間に大差はない。

謝 辞

本研究の遂行にあたり，終始熱心に実験に協力された 芝浦工業大学学生山琦二郎氏に深甚の謝意を表する。

\section{参考 文 献}

1) J. Kinugawa, T. Fukushima and S. Fukushima ; Development of shielding method with water jet and gas in underwater plasma welding. Trans. NRIM 16-5 (1974) $183-193$

2）品田幸三郎；局部乾式水中自趿浴接システムの開発，学位請求諭 文 (慶応義熟大学)、昭和56年，2-2 2-4


又溶接，金材技研報告，20-2 (1977) 82 97

4）福島孟；湿式水中溶接装罪，特許 $1217552 ，(1984)$

5）衣川，福島（孟），褔岛（貞）；水中に㧍けるブラズマ溶接，“本 誌 43-2 (1974) 192

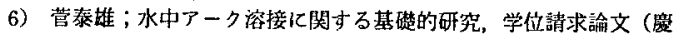
応義熟大学), 1977, 58 66

7）农川，福島（甾），福島（自）; 水中プラズマ溶接部の冷却，本 誌 44-10 (1975) 834 839

8）福島 (孟), 福島（貞）、或川；加压下におりる湿式水中ブラズマ 溶接の冷却特性と溶接金属の組織, 本誌 50-9 (1981) 887 893 